\title{
Medievalista
}

Online

$9 \mid 2011$

Número 9

\section{Morgan Le Fay: A Herança da Deusa. As Faces do Feminino na Mitologia Arturiana}

Tese de Mestrado em Literatura Inglesa apresentada à Faculdade de Letras da Universidade de Lisboa, em Setembro de 2010. Orientação da Prof. Doutora Angélica Varandas.

\section{Ana Rita Martins}

\section{(2) OpenEdition}

12 Journals

\section{Edição electrónica}

URL: http://journals.openedition.org/medievalista/660

DOI: 10.4000/medievalista.660

ISSN: 1646-740X

Editora

Instituto de Estudos Medievais - FCSH-UNL

Refêrencia eletrónica

Ana Rita Martins, « Morgan Le Fay: A Herança da Deusa. As Faces do Feminino na Mitologia Arturiana », Medievalista [Online], 9 | 2011, posto online no dia 02 janeiro 2011, consultado o 15 setembro 2020. URL : http://journals.openedition.org/medievalista/660 
Titulo: Apresentação de Tese

Morgan Le Fay: A Herança da Deusa. As Faces do Feminino na Mitologia Arturiana.

Tese de Mestrado em Literatura Inglesa apresentada à Faculdade de Letras da Universidade de Lisboa, em Setembro de 2010. Orientação da Prof. Doutora Angélica Varandas.

Autor(es): Ana Rita Martins

Enquadramento Institucional: Faculdade de Letras da Universidade de Lisboa Contacto: anna.rita.mart @gmail.com

Fonte: Medievalista [Em linha]. №9, (Dezembro 2010). Direc. José Mattoso. Lisboa: IEM. Disponível em: http://www2.fcsh.unl.pt/iem/medievalista/

ISSN: $1646-740 \mathrm{X}$ 


\section{Apresentação de Tese}

\section{Morgan Le Fay: A Herança da Deusa. As Faces do Feminino na Mitologia Arturiana.}

Tese de Mestrado em Literatura Inglesa apresentada à Faculdade de Letras da Universidade de Lisboa, em Setembro de 2010. Orientação da Prof. Doutora Angélica Varandas.

\section{Ana Rita Martins}

A presente tese tem por objectivo fazer um estudo aprofundado da figura de Morgan le Fay analisando os primórdios e a evolução desta personagem dentro do período medieval e o seu desenvolvimento a partir dessa altura até aos tempos modernos. Efectivamente, a problemática que rodeia a origem da personagem parece nunca ter deixado de seduzir autores e leitores que, desde cedo, procuraram explicar, ou justificar, a natureza enigmática e ambígua desta figura.

Neste trabalho, começámos por explorar as origens de Morgan le Fay, procurando também encontrar nos textos medievais alguma justificação para o carácter contraditório da personagem. De facto, embora a figura de Morgan revele já transformações muito claras e evidentes durante a Idade Média, a verdade é que, ao longo dos séculos, continuou a ser alvo de modificações as quais, por sua vez, contribuíram para a forma como para ela olhamos na actualidade. Partindo, pois, da Idade Média, traçámos um percurso cronológico pelos textos que se detiveram na figura enigmática de Morgan le Fay, tentando perceber os modos e causas das suas representações, interpretações e reinterpretações, que, naturalmente, afectaram o papel assumido por esta na arte contemporânea e na forma como ela é hoje encarada. 
A primeira referência ao famoso rei Artur surge na crónica Historia Brittonum escrita pelo monge galês Nennius ${ }^{1}$, cerca de $849-50$, aí não havendo, no entanto, qualquer referência a uma personagem que sequer se assemelhe a Morgan le Fay. De facto, Morgan, ou Morgen, só surgirá no panorama arturiano pela mão de Geoffrey of Monmouth, em 1150, na obra Vita Merlini (A Vida de Merlin). Todavia, ao examinar este texto, deparámo-nos com um factor que muito nos surpreendeu: onde está a figura da feiticeira cruel e ambiciosa tradicionalmente associada a Morgan? Quem é esta Morgen cuja descrição se assemelha à de uma rainha com poderes extraordinários? Qual é afinal a sua relação com Artur? É ela sua irmã ou sua amante? É ela humana ou sobrenatural? Perante tantas dúvidas, ficou claro ser necessária uma pesquisa que se concentrasse em textos anteriores ao de Geoffrey of Monmouth. Neste sentido, de modo a tentar descobrir os primórdios de Morgan e encontrar uma possível explicação para as suas características aparentemente paradoxais, iniciámos a nossa reflexão pelas fontes das lendas arturianas: os mitos célticos preservados, ao longo da Idade Média, nos manuscritos irlandeses e também nos manuscritos galeses ${ }^{2}$. A análise destes textos e de vários estudos críticos medievais sobre as origens de Morgan le Fay, permitiu-nos concluir que esta personagem possui afinidades profundas com a deusa A Morrígan da mitologia céltica irlandesa. Ao percebermos ainda ser a figura feminina extremamente relevante para a religião dos Celtas, os quais viam nos fenómenos naturais a presença de uma divindade suprema que assumia um rosto e um corpo femininos, compreendemos que importava conhecer melhor o povo céltico e os seus mitos.

Os mitos célticos fazem parte dos mais antigos cultos de vegetação e fertilidade das comunidades primitivas para quem o divino se revelava como encarnação da própria terra, capaz de se manifestar de diferente formas, mas sempre sob um semblante

\footnotetext{
${ }^{1}$ Os manuscritos são anónimos, havendo actualmente críticos que tenham posto em causa a autoria de Nennius, daí, que alguns se refiram ao autor de Historia Brittonum como Pseudo-Nennius.

${ }^{2}$ Os mitos célticos irlandeses estão preservados em múltiplos manuscritos, sendo de destacar: $O$ Livro de Dun Cow (anterior a 1106); O Livro de Leinster (escrito antes de 1160); o Rawlinson B 502 (contendo páginas produzidas antes do século XI e XII); e O Livro Amarelo de Lecan, O Grande Livro de Lecan, $O$ Livro de Hy Many e $O$ Livro de Ballymote de finais do século XIV e princípios do século XV. Entre as fontes galesas, é de destacar The Mabinogion, um conjunto de histórias bastante antigas com origem na tradição oral céltica acreditando-se que, e embora não haja consenso entre os críticos quanto a datas exactas, Os Quatro Ramos do Mabinogi tenham sido escritos na segunda metade do século XI enquanto os restantes textos terão sido registados mais tardiamente. Primeiro traduzidos para inglês por Lady Charlotte Guest, responsável pela introdução de Taliesin na colecção, os contos do The Mabinogion só se tornaram conhecidos no século XIX.
} 
feminino. O mundo natural ganhava, pois, uma dimensão divina: a terra era uma Grande Deusa, ou Deusa Mãe, ora meiga e fértil, como a Primavera; ora cruel e estéril como o Inverno. Assim, o primeiro capítulo desta dissertação funciona como contextualização sócio-cultural, explorando a cultura, crenças e organização social dos Celtas.

De modo geral, as tribos célticas organizavam-se em grupos, famílias, províncias ou reinos, estando, cada um, submetido a um rei e a um druida cuja relação é imprescindível para o bom funcionamento da comunidade. A organização sócio-cultural das tribos era, por sua vez, baseada numa estrutura tripartida herdada do povo IndoEuropeu. Além do rei, cada comunidade tinha três grupos sociais distintos: a classe sacerdotal, a classe guerreira e a classe produtora.

A classe sacerdotal incluía druidas, sacerdotes, adivinhos, curandeiros, bardos e poetas sendo altamente hierarquizada e com vários graus de especialização. Os druidas, em especial, detinham grande prestígio e desempenhavam funções do foro religioso, cabendo-lhe o papel de representantes dos deuses. A sua associação ao rei, detentor do poder temporal, era crucial, como prova, aliás, a relação entre Merlin e Artur no ciclo arturiano. O rei, por seu lado, provinha da classe guerreira e era responsável pelo cumprimento das leis adoptadas em assembleia, estando, porém o poder deste limitado por uma série de proibições de carácter mágico e religioso (geasa). Era ainda seu dever garantir o bem-estar do reino sendo da sua saúde física e mental que dependia o vigor da terra. Efectivamente, para assegurar a fecundidade, era necessário garantir o casamento ritual entre o Deus Tribal, papel desempenhado pelo monarca, e a Grande Deusa, representada por uma mulher ou qualquer outro símbolo da terra. O laço entre o rei e a Grande Deusa assemelhava-se, pois, a um contrato matrimonial que caso quebrado dava início a um período de destruição e infertilidade. Por fim, a classe produtora era composta, em grande parte, por artífices, embora pudesse compreender qualquer pessoa com um dom natural ou artístico. É de realçar a importância deste grupo, porque, nas comunidades célticas, todos os que conseguissem trabalhar o ferro eram louvados, chegando alguns membros a ostentar títulos semelhantes ao de doutor ou mesmo de druida.

Ao atestar a centralidade da figura feminina na cultura e na religião dos Celtas, pudemos então avaliar a importância de A Morrígan, na mitologia céltica irlandesa, a sua relação com Modron, figura paradigmática dos mitos galeses, e como ambas 
participam na génese de Morgan le Fay. A Morrígan é particularmente relevante, pois é da sua ligação com O Dagda ${ }^{3}$, um dos líderes dos Tuatha Dé Danann ${ }^{4}$, que renasce a ordem e o equilíbrio da natureza. Além disso, esta é também notável por ser, juntamente com Macha e Badb ou Nemain, uma das faces das Morrígna, divindade associada à guerra e responsável por incentivar o espírito bélico dos guerreiros e influenciar os acontecimentos no campo de batalha. De facto, ainda que alguns críticos tenham vindo recentemente desacreditar a relação A Morrígan/Morgan, a verdade é que as lendas arturianas e suas personagens radicam, na sua maioria, na mitologia e principais divindades célticas. Tal como a figura de Merlin, criada por Geoffrey of Monmouth em Prophetiae Merlini (Profecias de Merlin), cerca de 1135, encontra eco na figura do profeta galês Myrdin, também Morgan le Fay, que surge pela primeira vez na obra Vita Merlini, do mesmo autor, remonta às deusas do passado céltico, possuindo claras afinidades com A Morrígan e com Modron. Com efeito, A Morrígan está ainda ligada à divindade aquática galesa Modron a qual partilha com Morgan le Fay uma aparente origem comum, pois Morgan, nome que pode querer dizer "mulher que veio do mar", é também de origem marinha, o que reflecte igualmente a sua ligação com Avalon. Adicione-se o facto de as duas (Modron e Morgan) se terem unido a Urien e de com ele terem um filho, Owain ou Yvain.

Contudo, convém ter sempre presente que, embora a cultura céltica seja pagã, os manuscritos que contêm as principais narrativas e poemas relacionados com os Celtas pertencem já à era cristã. Na verdade, as primeiras referências às comunidades célticas são feitas por historiadores helénicos visto as anteriores não recorrerem à escrita para registar a sua história. Os textos clássicos, no entanto, são fragmentados, pouco desenvolvidos e não revelam com pormenor a organização social dos Celtas. Apenas séculos mais tarde é que os mitos e lendas deste povo foram registados, não por aqueles

\footnotetext{
${ }^{3}$ O deus tribal, O Dagda, figura de tal forma importante que o seu nome, tal como o de A Morrígan, surge normalmente antecedido pelo artigo definido, é um dos líderes dos Tuatha Dé Danann. Quando Júlio César primeiro identifica as divindades célticas, O Dagda é comparado a Júpiter, imperador dos céus, sendo reconhecido como patrono dos druidas, médicos e deus da amizade. Adicionalmente, esta deidade preside às estações e colheitas, tendo, todavia, na forma de Ogma, o seu par indissociável, uma parte negra e sombria. O Dagda é também pai de Óengus ou Mac Óc, ou ainda, Mabon.

${ }^{4}$ Os contos mitológicos irlandeses situam nos Tuatha Dé Danann, povo da deusa Ana, Dana ou Danu, a origem do povo céltico. De acordo com o Livro das Invasões (século XII), esta tribo foi a quinta a instalar-se na Irlanda e, por isso, responsável pela derrota dos Fir Bolg. Porém, o seu reinado terminou com a chegada dos Milesianos que obrigou o povo de Ana a refugiar-se em locais isolados e recônditos. Com o passar do tempo, os Tuatha Dé Dannan transformaram-se nos Sídhe ou fadas.
} 
que lhes deram origem, mas por monges que viriam a suprimir das narrativas alguns elementos que poderiam abalar os fundamentos da fé cristã. Do mesmo modo, Morgan le Fay, enquanto criação literária de Geoffrey of Monmouth, não obstante as suas antepassadas míticas, é uma personagem que emerge da civilização medieval judaicocristã.

A disseminação da religião cristã na Europa traz consigo uma profunda alteração na mentalidade e comportamentos, pois, ao contrário do que acontecia nas comunidades célticas onde as mulheres detinham um estatuto semelhante ao dos homens, o género feminino passa a ser visto como inferior e o seu papel limitado ao serviço dos homens. Com efeito, aquando da difusão da religião cristã, assiste-se ao engrandecimento de um Pai omnisciente e omnipresente. A Virgem Maria torna-se na única mulher apresentada como excepcional e inigualável, mas mortal, embora seja ela que possibilita a redenção ao dar à luz o Messias. Além disso, a narração do Génesis, onde Deus criou Eva a partir de uma costela de Adão, torna-se num momento chave para estabelecer o que a Igreja Católica apelida de «ordem natural», segundo a qual a mulher deve submeter-se ao homem. Ao mesmo tempo, estabelece-se uma visão do género feminino essencialmente dominada por duas figuras: Eva, a pecadora, e Maria, a santa.

Eva, representante do sexo feminino no Paraíso, é encarada como a grande culpada pela Queda da humanidade, e é responsabilizada pela propagação do pecado aos seus descendentes. A Virgem Maria, por seu lado, é a única capaz de conceber sem pecado. Livre da maldição do acto de procriar, ela é ímpar entre as mulheres, tornando-se, por isso, um modelo impossível de seguir. Será apenas entre os séculos XI e XII, e a partir da necessidade de recompensar as boas cristãs casadas, que surge uma terceira via: Maria Madalena, a pecadora arrependida. É ela a responsável pela abertura das portas do Paraíso para qualquer penitente. Transformada num símbolo da fragilidade humana, Madalena perfila-se entre Eva, a mulher real, e Maria, a mulher ideal. Contudo, o papel da mulher como símbolo do pecado não se modifica de modo significativo dado a salvação só poder advir do arrependimento e da penitência.

Após reunir esta informação, regressámos, inevitavelmente, à obra de Geoffrey of Monmouth, Vita Merlini, sendo, no entanto, evidente que outro texto do mesmo autor teria de ser considerado: História dos Reis Britânicos (Historia Regum Brittaniae) de 1136. Este último, anterior a Vita Merlini, influenciou, em larga escala, as narrativas 
arturianas, estabelecendo a árvore genealógica de Artur e mencionando, pela primeira vez, a irmã de Artur Pendragon, Anna ou Anne. Estávamos, logo, perante duas figuras distintas: por um lado, Anna ou Anne, irmã de Artur, e, por outro, Morgen, soberana com poderes sobrenaturais. Colocava-se assim um novo problema: Morgan le Fay parece reunir características tanto de Anna ou Anne, quanto de Morgen. Teriam as duas, de algum modo, sido interligadas, dando origem a uma só personagem? A esta questão dedicámos o segundo capítulo, onde concluímos dever-se esta alteração às semelhanças entre as deusas A Morrígan e Ana, Dana ou Danu, mãe divina dos Tuatha Dé Danann.

A similitude entre os nomes, Anna, a irmã de Artur, e Ana, divindade, parece indiciar uma possível ligação entre as duas figuras feminina que é comprovada na obra The White Goddess, de Robert Graves, na qual o autor declara que Anna, cujo significado pode ser "rainha" ou "deusa mãe", faz parte da mitologia irlandesa, aparecendo precisamente sob a forma da deusa Ana ou Anan. Adicionalmente, Graves defende que esta divindade, à semelhança de outras na mitologia céltica, podia assumir dois semblantes: por um lado, existia Danu ou Ana, a beneficente, e, por outro, Ana, a maléfica, que, com Badb e Macha, fazia parte das Morrígna. Estando as Morrígna ligadas ao campo de batalha, Ana, um dos seus rostos, pode, por certo, ser considerada uma deusa da guerra. Mas e A Morrígan? Na sua explicação, Graves não menciona esta divindade indissociável das Morrígna, parecendo haver quase que uma substituição de A Morrígan por Ana. Deste modo, e caso tenha havido de facto uma troca de identidades entre as duas, Ana e A Morrígan, é susceptível assumir que as personagens, Anna e Morgen dos contos arturianos, foram também afectadas. Esta mudança justificaria, aliás, por que razão esta última, na sua descrição inicial em Vita Merlini, não tem qualquer relacionamento com a família do rei. A difusão das narrativas arturianas vai assim apagar o nome de Anna, a irmã de Artur de acordo com a genealogia estabelecida por Geoffrey of Monmouth, e dar lugar a Morgan le Fay, a Fada Morgana que passará a assumir a mesma relação familiar com o rei.

Adicionalmente, o segundo capítulo visa analisar como o desenvolvimento da cortesia e o papel da magia na Idade Média muito contribuíram para o aumento significativo do número de irmãs, ou meias-irmãs, de Artur. Numa época em que os casamentos eram um negócio conveniente, a ligação afectiva das mulheres aos seus irmãos e parentes é muito interessante, verificando-se que, mesmo após o casamento, as esposas e mães 
eram, em grande parte, leais à família da qual provinham, e daí encontrarem-se sobrinhos cuja fidelidade é para com o tio, irmão da sua mãe ${ }^{5}$. Todavia, no século XIII, não podemos deixar de notar uma baixa, ou estabilização, da quantidade de irmãs do rei Artur. Para explicar este fenómeno, alguns críticos têm apontado a redução da importância cultural dos laços entre irmãos, o que levaria a uma menor necessidade de cavaleiros notáveis pertencerem à linhagem de Artur. Além disso, assistiu-se a um aumento do poder da nobreza e ao progressivo destaque da cavalaria enquanto manifestação do poder divino. $\mathrm{O}$ valor e autoridade do sangue real começam a perder importância. Desta forma, podemos reduzir as meias-irmãs de Artur a um grupo de três: Elaine, Morgause/Morcades ou a Rainha de Orkney e Morgan le Fay, todas filhas de Igraine.

Continuando a traçar o percurso cronológico, chegámos pois o momento de nos determos no período medieval entre o século XII e o século XV, altura em que foram produzidos inúmeros textos (ingleses, franceses e não só) cuja fonte de inspiração eram as lendas relacionadas com Artur e com todo o imaginário cavaleiresco - nascia a Matéria da Bretanha ${ }^{6}$.

$\mathrm{Na}$ impossibilidade de abordar todos esses textos, optámos por analisar a figura de Morgan nas duas obras inglesas medievais mais representativas do universo arturiano e nas quais a feiticeira de Avalon desempenha um papel de destaque, são elas: Sir Gawain and the Green Knight (SGGK) e Le Morte D'Arthur de Thomas Malory. O terceiro capítulo tem, assim, por intuito compreender e explorar a(s) diferença(s) e semelhança(s) entre a Morgan (Morgne) descrita pelo Gawain-Poet e a Morgan le Fay de Malory.

Tanto SGGK como Le Morte D'Arthur são duas obras fundamentais para a compreensão de Morgan le Fay: a primeira, porque, inserindo-se no Revivalismo Celta do século XIV, vai invocar o papel primordial de Morgan enquanto um dos rostos da Grande Deusa céltica. $S G G K$ é um texto arturiano raro no mundo medieval inglês por

\footnotetext{
5 Ao unirmos esta questão social à importância da linhagem matriarcal na cultura céltica percebemos o porquê da lealdade de Gawain a Artur em Sir Gawain and The Green Knight (SGGK) onde o cavaleiro perspectiva o seu valor em relação ao tio, Artur, e não ao pai.

6 As histórias sobre Artur foram levadas para território francês pelos conteurs que, descendentes do Celtas, haviam fugido da Grã-Bretanha para a Armórica (hoje a Bretanha francesa) após a ocupação anglo-saxónica e lá disseminaram a fama de Artur. A designação "Matéria da Bretanha” deve-se, no entanto, ao poeta francês do século XII, Jean Bodel.
} 
várias razões. Primeiro, porque são escassas as obras escritas em Inglaterra sobre Artur; segundo, por ser um dos poemas medievais mais elaborados, não havendo o grande número de incoerências normalmente encontrado em fontes britânicas e francesas; terceiro, por recuperar a tradição céltica e usar motivos característicos da cultura inglesa (como por exemplo o ciclo das estações); e quarto, porque restaura a identidade précristã de algumas das personagens principais do ciclo arturiano: Gawain (Gawayn) e Morgan le Fay.

O Gawain-poet atribui a Morgan várias características tradicionais: ela é filha de Igraine e do Duque de Tintagel, que podemos presumir ser Gorlois; é meia-irmã do rei Artur e irmã da mãe de Gawain; foi aluna de Merlin (Merlyn), que por ela se apaixonou, e com ele aprendeu magia. Feiticeira influente, Morgan detém um papel indispensável no desenrolar da narrativa. É ela afinal a instigadora da acção. Porém, devemos lembrar que Morgan é uma figura silenciosa. Ao longo do poema, a sua presença mantém-se escondida, mas por trás dos movimentos das restantes personagens, a vontade desta mulher é suprema pondo e dispondo, qual jogo de xadrez, as peças em movimento. É a ela a quem é atribuída a responsabilidade da ida do Cavaleiro Verde à corte de Artur onde o primeiro irá desafiar os heróis de Camelot a participar num jogo de decapitação que depressa se tornará num desafio de coragem, fé e um teste aos valores da cavalaria e às normas e valores sociais implementadas pelo meio-irmão da feiticeira. Morgan le Fay é, em $S G G K$, uma figura ambígua: envia o Cavaleiro Verde (que mais tarde se revelará ser Sir Bertilak) para perturbar a paz da corte de Artur e assustar Guinevere (Guenore) de morte, mas, não obstante, os seus propósitos vão além do rancor pela rainha. As acções por si levadas a cabo visam testar, principalmente, o seu meio-irmão e demonstrar haver algo de podre em Camelot. Contudo, Morgan não consegue atingir os seus intuitos, porque, de facto, não assusta Guinevere e, acima de tudo, não consegue levar a corte de Artur a questionar os valores pelos quais se rege.

O restaurar da figura de Morgan reflecte-se, mais obviamente, em dois momentos do texto. Primeiro, no epíteto que lhe é dado por Sir Bertilak/Cavaleiro Verde - a deusa, "pe goddess" - "the Goddess" (SGGK verso 2452) - invocando o papel primordial de Morgan enquanto Senhora de Avalon. Alguns críticos têm argumentado ser o título de deusa apenas um cognome dado a Morgan por camponeses que viam nos seus poderes mágicos uma origem divina. De facto, o epíteto de deusa atribuído a Morgan surge, 
originalmente, pela mão de Giraldus Cambrensis (Gerald of Wales), na obra Speculum Ecclesiae (1216), onde o autor se refere a Morgan como "dea phantastica" (deusa imaginária). Segundo, o Gawain-Poet descreve Morgne e a Dama de Hautdesert em termos comparativos. Estas mulheres parecem mesmo ser duplos uma da outra e, mesmo não sendo unas, relembram os dois possíveis rostos da Grande Deusa que encarnava a própria terra e podia assumir uma face jovem e bela, trazendo a prosperidade, abundância e paz (Primavera) ou envelhecida e horrenda, portadora da esterilidade, conflito e morte (Inverno). Todavia, em $S G G K$, os dons mágicos da feiticeira são resultado da aprendizagem formal com Merlin o que coincide com a progressiva racionalização da personagem e consequente afastamento das origens pagãs. Além disso, embora $S G G K$ recupere temas e motivos de origem céltica, o autor não pode fugir à sua época, expressando, no discurso de Gawain sobre as mulheres, sentimentos ou ideais misóginos característicos do século XIV. Morgan revela já possuir poder sobre as outras personagens e vontade dominadora, mas não parece a feiticeira totalmente pérfida do universo francês e do que viria a acontecer na obra de Thomas Malory.

A segunda obra, Le Morte D'Arthur, escrita entre 1469 e 1470, é uma das mais importantes obras medievas sobre o rei Artur e os cavaleiros da Távola Redonda na qual vários textos são recontados, nomeadamente: Suite de Merlin, Morte Arthure, Tristan, Queste del Saint Graal, Lancelot en Prose e Mort de le Roi Artu. Malory usou, em grande parte e ao contrário do Gawain-poet, a tradição literária continental presente no Ciclo da Vulgata e da Pós-Vulgata. Assim, o autor deu continuidade ao processo de degradação que algumas das personagens mais antigas das lendas arturianas já tinham vindo a sofrer (Gawain é, de resto, disso exemplo) e reformulou as aventuras dos cavaleiros da Távola Redonda à luz do conceito de herói promovido pela Igreja Cristã. No centro das diversas histórias estão os cavaleiros, logo, não é de espantar que a trama seja dominada por juízos de valor masculinos. Ao homem cabe o papel activo, estando, de modo geral, nas suas mãos, o destino das damas. Seres secundários, as mulheres em Le Morte D'Arthur vivem em função de uma cultura patriarcal onde os direitos femininos são reduzidos à conveniência do homem por quem são representadas, seja esse seu pai, irmão ou tutor. A função primária da mulher é, pois, a de suporte dos heróis. Contudo, a proximidade com os cavaleiros e, muitas vezes, a sua presença, aquando do início e desenrolar dos mais extraordinários feitos cavalheirescos, vão 
garantir às damas um lugar de destaque enquanto forças motrizes por detrás das aventuras dos protagonistas. Le Morte D'Arthur é também uma obra fundamental, pois foi sobretudo a partir de Thomas Malory que Morgan Le Fay (Morgan le Fey) ficou para a história como a feiticeira má capaz de tudo para prejudicar o irmão.

No começo de Le Morte D'Arthur, Morgan tem uma boa relação com o meio-irmão, Artur, de tal forma que ele lhe confia a espada Excalibur e a bainha, ambas objectos sobrenaturais $^{7}$. No entanto, o bom relacionamento com Artur não impede Morgan de conspirar contra a vida do rei e do marido, o rei Urien (Uryens), falsificando os acessórios mágicos deixados à sua guarda e atraindo Artur para uma batalha com Accolon, amante da feiticeira. Será, aliás, este último quem confessa o terrível esquema elaborado para derrotar Artur, atribuindo a Morgan toda a culpa: foi ela quem decidiu atentar contra a vida de ambos os monarcas. É através de um homem, o qual se declara apaixonado pela esposa de Urien, mas facilmente a denuncia, que sabemos o porquê da rebelião da feiticeira. $\mathrm{O}$ amor por Sir Accolon, o desejo de se tornar rainha suprema e ocupar um lugar que a sociedade não lhe permitia servem de justificação para o comportamento da feiticeira. Não obstante, todos os planos de Morgan falham, não lhe restando senão o exílio imposto pelos homens da sua família. O conhecimento mágico permite-lhe, contudo, iludir Artur e continuamente minar o reinado dele. O poder dos encantamentos, ou necromancia, dá à feiticeira um estatuto similar ao do meio-irmão, visto ela conseguir impor a sua vontade independentemente da aprovação dele.

Em Le Morte D'Arthur, Morgan le Fay afasta-se da figura benéfica presente em Vita Merlini e do papel ambíguo representado em $S G G K$, assumindo-se agora como uma personagem negativa, uma das vilãs da narrativa. Poderosa pelas forças sobrenaturais que consegue manipular, ela é maligna, invejosa, ambiciosa e cruel, tentando por todos os meios prejudicar Artur. Porém, os verdadeiros motivos de Morgan mantêm-se envoltos em mistério e as suas acções não são, de modo geral, satisfatoriamente justificadas. Todavia, aquando da morte do rei, causada por Mordred, filho de Artur e da sua irmã Morgause (Margawse), é Morgan quem vem, numa barca, buscar o irmão para o curar, havendo um regressar ao papel desempenhado em Vita Merlini. Com a destruição da Távola Redonda, o modelo de comportamento promovido por Artur é

\footnotetext{
${ }^{7}$ Segundo Thomas Malory, a espada Excalibur, sempre que desembainhada numa luta, causava feridas aos seus oponentes, enquanto a bainha impedia aquele que a carregava de sofrer ferimentos.
} 
arruinado já não restando quaisquer motivos para continuar o conflito entre os dois. Perante a iminente morte do meio-irmão, a personagem Morgan le Fay transforma-se numa figura sobrenatural (quer reconheçamos nela a Grande Deusa dos Celtas ou não), passando a ser a responsável pela passagem para o Outro Mundo céltico que é Avalon, ou simplesmente para a morte.

O episódio da vinda da barca para buscar Artur é bastante interessante na medida em que combina diversos factores e nos leva a problematizar, de novo, o desempenho de Morgan, porque embora descrita desde o início como feiticeira maligna, a meia-irmã de Artur passa, nas últimas páginas de Le Morte D'Arthur, a rainha de Avalon, suprema conhecedora das artes curativas. Podemos, portanto, deduzir estarmos perante duas versões da figura Morgan le Fay: por um lado, a feiticeira cruel e ambiciosa que domina quase todo o texto, e, por outro lado, a Senhora de Avalon, figura sobrenatural pagã. Parece-nos pois ter Malory tentado conjugar duas tradições distintas e opostas da mesma personagem, uma, de origem continental, onde Morgan é, basicamente, a vilã, e outra, proveniente da herança inglesa, na qual a mesma personagem tem características que, embora ambíguas, são positivas. Cria-se assim um dualismo ímpar nas narrativas arturianas que irá marcar o comportamento de Morgan ao longo dos séculos.

Após o século XV até ao século XIX há um período de interregno das lendas arturianas devido a) ao crescente interesse pela cultura clássica, agora, entendida como Idade de Ouro; e b) ao repúdio pelas línguas bárbaras (vernáculas) e pela cultura e literatura medievais. O quarto e último capítulo visa, portanto, olhar para séculos recentes e perceber como Morgan le Fay é representada por autores ou artistas modernos, procurando ainda identificar os textos medievais que lhes serviram de fonte.

De facto, as lendas sobre Artur só serão recuperadas a partir de finais do século XVIII, período de revivalismo marcado por uma crescente curiosidade pelas culturas e tradições primitivas. Em Inglaterra, particularmente, este interesse reflectiu-se na busca de um passado nacional. Ao mesmo tempo, assistem-se a grandes mudanças na cena literária e intelectual (bem como no panorama político-social) que irão culminar no despontar do Romantismo. O movimento romântico ${ }^{8}$ vai pautar as primeiras décadas do

\footnotetext{
${ }^{8}$ O movimento romântico vai marcar, de forma incontornável, as primeiras três décadas do século XIX, sendo o prefácio de William Wordsworth à reedição das Lyrical Ballads (1800), obra escrita com Samuel Taylor Coleridge, considerado o início do Romantismo inglês.
} 
século XIX e terá como fonte de inspiração o mundo natural, a magia, os mitos antigos e a época medieva. É neste contexto que se assiste ao reaparecimento das narrativas arturianas, sendo Le Morte D'Arthur alvo de especial interesse por parte do público vitoriano. Baseando-se na narrativa de Thomas Malory, os autores novecentistas vão produzir inúmeras obras, contribuindo para a popularização das lendas arturianas. Com efeito, a maioria vai ficar a conhecer as narrativas sobre o rei Artur via as reinterpretações feitas pelos escritores e nos quadros produzidos pelos artistas da época, nomeadamente pelos Pré-Rafaelitas.

A primeira fase do que, mais tarde, seria reconhecido como o movimento Pré-Rafaelita inicia-se em 1848, data do início da Irmandade Pré-Rafaelita (Pre-Raphaelite Brotherhood, PRB) ${ }^{9}$. A PRB ambicionava inovar em diversos campos procurando associar-se a um período histórico e artístico muito particular, o da era antes de Rafael, ou seja, a Idade Média. Todavia, a visão destes oito Pré-Rafaelitas é a de um passado idealizado, pois a Idade Média era para eles um período harmonioso durante o qual o Homem e a natureza viviam em equilíbrio. Além disso, a PRB identifica-se com os ideais de cavalaria, em especial os princípios de lealdade, fraternidade e coragem perpetuados pelas narrativas sobre os cavaleiros da Távola Redonda. Utilizando, maioritariamente, Le Morte D'Arthur, mas também os poemas de Lord Tennyson, os Pré-Rafaelitas dedicar-se-ão a representar nos seus quadros cenas descritas pelos dois escritores. O fim da PRB dá-se em 1854; porém, os princípios defendidos pela Irmandade vão ser alvo de admiração por parte de um grupo disperso, dando origem à chamada segunda fase do movimento Pré-Rafaelita que vai incluir artistas de renome, distinguindo-se: Edward Burne-Jones, John William Waterhouse, William Morris, Evelyn De Morgan e Frederic Sandys.

A arte Pré-Rafaelita irá continuar a influenciar pintores: a sua visão de Morgan le Fay como a mulher independente, misteriosa e maléfica cujo conhecimento, neste caso sobre magia, lhe permite impor-se e contrariar os desejos do tutor masculino, o irmão, Artur, permaneceu e, em larga escala, contribuiu para a formação da imagem actual da

\footnotetext{
9 A PRB conta com oito artistas: William Holman Hunt, John Everett Millais, Dante Gabriel (DG) Rossetti, Thomas Woolner, James Collinson, Frederic George Stephens e William Michael Rossetti, irmão mais novo de DG Rossetti.
} 
personagem $^{10}$. Além disso, saliente-se que a perspectiva romântica Pré-Rafaelita irá igualmente dominar a ficção europeia e americana do século XX.

No século XX, os textos ligados ao rei Artur e aos cavaleiros da Távola Redonda tiveram enorme popularidade, havendo inúmeros autores a escreverem, e reescreverem, as aventuras dos heróis arturianos, dando maior preponderância a várias personagens femininas. Também a nível visual há cada vez um maior interesse em representar figuras associadas a Camelot, em particular, Morgan le Fay e Guinevere. O início do século XX assistiu, pois, à produção de numerosas obras sobre a Matéria da Bretanha, entre as quais salientamos: A Connecticut Yankee in King Arthur's Court de Mark Twain, que, produzida ainda no século XIX (é datada de 1889), é considerada a primeira narrativa moderna sobre o rei Artur; The Once and Future King de T.H. White, colecção que começa a ser publicada em 1938; e Taliessin Through Logres (1938) e The Region of the Summer Stars (1944) de Charles Williams. Adicionalmente, com o rápido desenvolvimento da indústria cinematográfica a partir de então, começam a surgir vários filmes onde a corte de Camelot é central para o guião ${ }^{11}$. De destacar Excalibur (1981), de John Boorman, no qual é dado a Morgan ou Morgana um papel fulcral.

Nos anos 70 do século XX, o revivalismo produzido pelo século XIX veio a ser assimilado para o cinema e música popular. Os mitos, e os mitos arturianos, em particular, estavam no centro da cultura da juventude. O gosto pelo primitivo e elementar, pela visão romântica da Idade Média, explorada (e, em parte, criada) pelos Pré-Rafaelitas, reflectiu-se nas salas de cinema. Uma década mais tarde, nos anos 80, a mitologia e o imaginário medieval já integravam a cultura popular europeia e americana, manifestando-se nas mais diversas áreas. O filme Excalibur distingue-se de outras representações cinematográficas da corte arturiana, pois este filme, além de colocar Morgan numa posição de poder, é possivelmente uma das melhores interpretações, ou reinterpretações, da Matéria da Bretanha.

\footnotetext{
${ }^{10}$ Entre as inúmeras obras Pré-Rafaelitas dedicadas à temática arturiana são destacadas: Morgan Le Fay (1862-3) de Anthony Frederick Sandys e a ilustração Morgan le Fay was put to school in a nunnery, and there she learned so much that she was a great clerk of necromancy (1910-11) de William Russell Flint. Além disso, é ainda de referir a ilustração de Aubrey Beardsley, Morgan le Fay gave a shield to Sir Tristam (1893-94).

${ }^{11}$ Entre os filmes dedicados à Matéria da Bretanha conta-se: Knights of the Round Table (1953), de Richard Thorpe; The Sword in the Stone (1962), de Wolfgang Reitherman; Camelot (1967), de Joshua Logan; Monty Python and the Holy Grail (1975), de Terry Gilliam e Terry Jones; First Knight (1995), de Jerry Zucker; e King Arthur (2004), de Antoine Fuqua.
} 
Baseando-se na obra Le Morte D'Arthur de Thomas Malory, Boorman centra-se no desenvolvimento de figura de Artur desde a concepção (através de um feitiço de Merlin) até à morte (via a interferência mágica de Morgan). Neste filme, Morgan é claramente, a figuração do Mal, que, excepto pelo trauma de infância causado quando o pai morre e a mãe é enganada, não tem quaisquer características redentoras - dela nem sequer é o papel (tradicionalmente desempenhado pela feiticeira) de levar Artur para Avalon, pois não parece estar dentro da barca que vem buscar o rei no fim do filme. Movida pela ganância e desejo de poder, Morgan assume, sem dúvida, o papel da mulher activa e dominadora - a predadora que surge para trazer a vingança e a destruição. Esta representação de Morgan, será, contudo, contrariada por uma das mais influentes obras literárias dedicada à temática arturiana The Mists of Avalon (1982) de Marion Zimmer Bradley.

The Mists of Avalon, publicado apenas um ano depois de Excalibur, é possivelmente o mais famoso e influente recontar das lendas arturianas do século XX. Composta por quatro livros: Mistress of Magic, The High Queen, The King Stag e The Prisoner in the Oak, a colecção de Marion Zimmer Bradley revolucionou a forma como as personagens femininas haviam sido representadas e interpretadas, em particular Morgaine, ou Morgan le Fay. Ao recontar o mito arturiano sob uma perspectiva (até então) completamente inovadora, Bradley consegue criar uma empatia entre o leitor e Morgan e redesenha a hierarquia de Camelot, criando uma da sociedade na qual a figura masculina se submete às influências, decisões e posturas dos elementos femininos - a verdadeira fonte de poder por detrás dos eventos principais. O trabalho de Marion Zimmer Bradley é, porém, uma excepção porque procura veicular uma visão alternativa, dando-se proeminência a uma cultura centrada na mulher. Há, por isso, uma contextualização diferente à presente em $S G G K$, Le Morte D'Arthur e Excalibur (bem como nos restantes quadros e ilustrações mencionados ao longo da dissertação). Bradley criou um argumento distinto dos anteriores, mas não transformou nem Artur, nem os seus cavaleiros em vilões. De facto, em The Mists of Avalon, não se pode traçar uma fronteira definida entre personagens boas e más. A própria Morgan foi humanizada, pelo que não a podemos considerar uma personagem de características totalmente positivas. Embora muitos considerem Morgan uma das grandes heroínas de The Mists of Avalon, é inegável que ela nem sempre se comporta como tal. Morgan, mesmo descrita enquanto tolerante e generosa, continua a ser quem contribui, directa ou indirectamente, 
para a morte de várias outras personagens masculinas e femininas e aquela que tenta assassinar o meio-irmão. Ela não é, com certeza, uma heroína por completo, mas pela sua complexidade de emoções e pensamentos, e pelo facto de se assumir como narrador principal da obra, está, sem dúvida, mais perto do leitor ou espectador do que antes.

Todavia, The Mists of Avalon, por mais preponderante que seja, não vai alterar por completo a representação de Morgan le Fay, verificando-se continuar a feiticeira, na maioria das obras literárias e cinematográficas, a ser vista sob uma luz negativa. Um bom exemplo disso é a banda desenhada onde Morgan assume quase sempre o papel de vilã cruel e ambiciosa. Mencionada, desde os anos 50, sob diferentes pseudónimos em inúmeras publicações de grande editoras americanas como a Marvel e DC Comics, é-lhe dado particular destaque na colecção Camelot 3000 de Mike Barr e Brian Bolland. Baseada em Le Morte D'Arthur, Camelot 3000 foi publicada entre 1982 e 1985, combinando elementos da obra de Thomas Malory com um cenário futurista.

No ano 3000, a Terra é invadida por seres alienígenas, iniciando uma série de eventos que irão levar à descoberta do túmulo de Artur Pendragon, à libertação de Merlin e ao restaurar da Távola Redonda. Morgan le Fay aparece nesta colecção num papel não muito diferente do representado em Excalibur: ela é maligna, egoísta, gananciosa e inveja o trono do meio-irmão. Visualmente as duas são parecidas, pois, embora Morgan (em Excalibur) seja loira e Morgan le Fay (em Camelot 3000) morena, ambas são mulheres fatais, cuja sensualidade é usada como um trunfo. Morgan le Fay, conforme no filme Excalibur, é a predadora, a devoradora de homens.

Verificamos, deste modo, que, embora no século XX, tenha havido uma reinterpretação das acções e motivos de Morgan le Fay, para os quais, de resto, se procurou alguma justificação, vindo a personagem adquirir algumas características positivas, ainda assim a imagem que dela permaneceu foi a de uma figura maléfica. $O$ percurso da feiticeira, agora, de modo geral, marcado por um desejo de reconhecimento pessoal e de igualdade para com os homens, continua a ser pautado por uma visão negra.

Concluindo, Morgan le Fay continua a ser encarada como vilã, primeiro, porque na passagem para o século XX, as representações dos mitos arturianos feitas pelos artistas Pré-Rafaelitas contribuíram, em larga escala, para a visão de outros pintores, ilustradores, realizadores cinematográficos e escritores. Assim, a degradação da imagem de Morgan le Fay perseverou e é dada continuidade à figura da bruxa maléfica, mas 
sensual, já presente na imaginação do público vitoriano. É, portanto, essa forma que chega até nós no filme Excalibur e no livro de banda desenhada Camelot 3000, ambos, de resto, expressamente baseados na narrativa de Thomas Malory. De facto, é de salientar a extrema importância de Le Morte D'Arthur como obra de referência para quem queira estudar, escrever ou fazer qualquer trabalho sobre o ciclo arturiano. A narrativa de Malory é um texto incontornável para o desenvolvimento das lendas arturianas conforme as conhecemos nos dias de hoje e, daí, que a representação feita de Morgan le Fay no texto seja também difícil de ser alterada - ela está enraizada no nosso imaginário colectivo.

Segundo, relacionado com o ponto atrás mencionado, o rei Artur e os seus cavaleiros, Gawain, Lancelot, Galahad, Bors, Percival, etc., são heróis por excelência, os mais corajosos e justos. Estando o renome destes cavaleiros além de qualquer suspeita, os que a eles se opõem são, diríamos, obrigatoriamente maus. Os romances, e os de cavalaria em particular, estão ligados a ideias pré-definidas sobre o Bem e o Mal. Os bons são destemidos, protegem os inocentes e as suas acções são honestas, logo, todos quanto tiverem posturas diferentes e que, de algum modo, se contraponham aos anteriores são, por norma, os maus ou vilões. Assim, se Artur é o herói, então Morgan, como sua declarada inimiga, é (e, de certo modo, só pode ser) a vilã.

Terceiro, parece-nos haver quase uma incapacidade de reavaliar o papel desempenhado por Morgan le Fay que, por mais incongruências que lhe possamos encontrar, não nos parece ser possível de alterar. A feiticeira ambiciosa, diabólica, sem escrúpulos está interligada com a imagem da femme fatale e curandeira sobrenatural, rainha do Outro Mundo que é Avalon - repetimos por isso que esta representação de Morgan le Fay está presente no nosso imaginário colectivo e dificilmente será alterada, tem o peso de séculos de tradição. 


\section{COMO CITAR ESTE ARTIGO}

\section{Referência electrónica:}

MARTINS, Ana Rita - Morgan Le Fay: A Herança da Deusa. As Faces do Feminino na Mitologia Arturiana. Tese de Mestrado em Literatura Inglesa apresentada à Faculdade de Letras da Universidade de Lisboa, Setembro de 2010. Medievalista [Em linha]. Nº9, (Dezembro de 2010). [Consultado dd.mm.aaaa]. Disponível em http://www2.fcsh.unl.pt/iem/medievalista/MEDIEVALISTA9Imartins9008.html. ISSN 1646-740X.

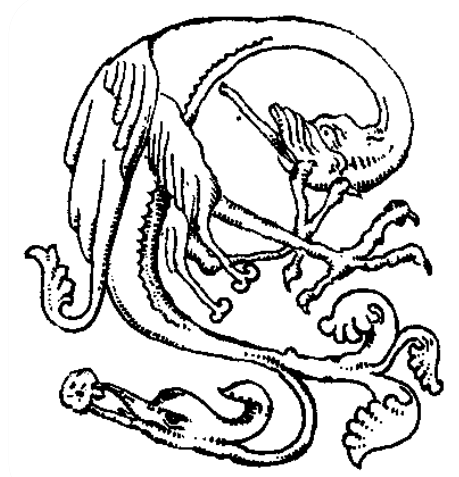

